ESSENTIAL READINGS IN ECONOMICS 


\section{ESSENTIAL READINGS IN ECONOMICS}

Edited by

Saul Estrin

London Business School

and

Alan Marin

London School of Economics 
Selection, editorial matter and Introduction ( ) Saul Estrin and Alan Marin 1995 Softcover reprint of the hardcover 1st edition 1995

For individual chapters, please see the Acknowledgements.

All rights reserved. No reproduction, copy or transmission of this publication may be made without written permission.

No paragraph of this publication may be reproduced, copied or transmitted save with written permission or in accordance with the provisions of the Copyright, Designs and Patents Act 1988, or under the terms of any licence permitting limited copying issued by the Copyright Licensing Agency, 90 Tottenham Court Road, London W1P 9HE.

Any person who does any unauthorised act in relation to this publication may be liable to criminal prosecution and civil claims for damages.

First published 1995 by

MACMILLAN PRESS LTD

Houndmills, Basingstoke, Hampshire RG21 2XS

and London

Companies and representatives

throughout the world

ISBN 978-0-333-59452-0 ISBN 978-1-349-24002-9 (eBook)

DOI 10.1007/978-1-349-24002-9

A catalogue record for this book is available from the British Library.

$\begin{array}{llllllllll}10 & 9 & 8 & 7 & 6 & 5 & 4 & 3 & 2 & 1\end{array}$

$\begin{array}{llllllllll}04 & 03 & 02 & 01 & 00 & 99 & 98 & 97 & 96 & 95\end{array}$

Typeset in 10/12 pt by EXPO Holdings, Malaysia 


\section{Contents}

Acknowledgements

ix

Introduction

S. Estrin and A. Marin

\section{PART I THEORY OF CONSUMER DEMAND}

1 The Law of Consumer's Demand

J. R. Hicks

\section{PART II THEORY OF THE FIRM AND SUPPLY}

2 The Nature of the Firm

R. H. Coase

3 The Concept of Monopoly and the Measurement of Monopoly Power

A. Lerner

4 Monopoly and Resource Allocation

A. C. Harberger

5 Strategic Competition among the Few - Some Recent Developments in the Economics of Industry

J. Vickers

\section{PART III GENERAL EQUILIBRIUM AND WELFARE}

6 The Anatomy of Market Failure

F. Bator 
7 Diagrammatic Exposition of a Theory of Public Expenditure

P. A. Samuelson

\section{PART IV ECONOMICS OF UNCERTAINTY AND INFORMATION}

8 The Market for 'Lemons': Quality Uncertainty and the Market Mechanism G. Akerlof

\section{PART V INFLATION AND UNEMPLOYMENT}

9 How Important is it to Defeat Inflation? The Evidence R. Bootle

10 The Role of Monetary Policy M. Friedman

11 Inflation and Unemployment 232 J. Tobin

\section{PART VI THE NATURE OF UNEMPLOYMENT}

12 Unemployment Policy

R. E. Lucas, Jr.

13 On Theories of Unemployment R. M. Solow

14 Efficiency Wage Models of Unemployment J. Yellen

\section{PART VII THE BUSINESS CYCLE}

15 The State of Long-Term Expectation J. M. Keynes

16 Understanding Business Cycles R. E. Lucas, Jr.

17 Real Business Cycles: A New Keynesian Perspective N. G. Mankiw 


\section{PART VIII CONTROL OF MACROECONOMIC} FLUCTUATIONS

18 A Monetary and Fiscal Framework for Economic Stability 345 M. Friedman

19 Rational Expectations and the Theory of Economic Policy 366 $T$. J. Sargent and N. Wallace

20 The Monetarist Controversy, or, Should we Forsake Stabilization Policies?

F. Modigliani

Index 


\section{Acknowledgements}

The editors and publishers wish to thank the following for permission to use copyright material:

American Economic Association and the authors, for A. C. Harberger, 'Monopoly and Resource Allocation', American Economic Review (1954), pp. 77-87; M. Friedman, The Role of Monetary Policy', American Economic Review, 58 (1) (March 1968), pp. 1-17, and M. Friedman, 'A Monetary and Fiscal Framework for Economic Stability', American Economic Review, 38 (3) (June 1948), pp. 245-64; J. Tobin, 'Inflation and Unemployment', American Economic Review, 62 (March 1972), pp. 1-18; R. E. Lucas, Jr., 'Unemployment Policy', American Economic Review, 68 (2) (May 1978), pp. 353-7; R. M. Solow, 'On Theories of Unemployment', American Economic Review, 70 (1) (March 1980), pp. 1-11; J. Yellen, 'Efficiency Wage Models of Unemployment', American Economic Review, Papers and Proceedings, 74 (2) (May 1984), pp. 200-5; F. Modigliani, 'The Monetarist Controversy...', American Economic Review, 67 (2) (March 1977), pp. 1-17; N. G. Mankiw, 'Real Business Cycles: A New Keynesian Perspective', Journal of Economic Perspectives, 3 (3) (Summer 1989), pp. 79-89.

Blackwell Publishers, for R. H. Coase, 'The Nature of the Firm', Economica, 1937, pp. 386-405.

Elsevier Science B. V., for T. J. Sargent and N. Wallace, 'Rational Expectations and the Theory of Economic Policy', Journal Of Monetary Economics (July 1976), pp. 199-214; and R. E. Lucas, Jr., 'Understanding Business Cycles' in K. Brunner and A. Meltzer (eds), Stabilization of the Domestic International Economy, Vol. 5, Carnegie-Rochester Series on Public Policy (1977), pp. 7-29. 
Macmillan Ltd, Cambridge University Press and RES, for J. M. Keynes, The General Theory of Employment, Interest and Money, Chap. 12 (1936), pp. 147-64.

The MIT Press, for F. Bator, 'The Anatomy of Market Failure', Quarterly Journal of Economics (1958), pp. 351-79; and G. Akerlof, 'The Market for "Lemons": Quality Uncertainty and the Market Mechanism', Quarterly Journal of Economics (1970), pp. 488-500.

Oxford University Press, for J. R. Hicks, Value and Capital, Chap. 2, 2nd edn (1946; 1st edn 1939), pp. 26-41; and John Vickers, 'Strategic Competition Among the Few: Some Recent Developments in the Economics of Industry', Oxford Review of Economic Policy, 1, 3 (1985), pp. 39-62.

Review of Economic Studies Ltd, for A. Lerner, 'The Concept of Monopoly and the Measurement of Monopoly Power', Review of Economic Studies (1934) 2, pp. 157-75.

The Royal Bank of Scotland plc, for R. Bootle, 'How Important is it to Defeat Inflation? The Evidence', The Three Banks' Review (Dec. 1981), pp. 23-47.

Paul A. Samuelson, for 'Diagrammatic Exposition of a Theory of Public Expenditure', Review of Economics and Statistics, 21 (May 1955), pp. 350-6.

Every effort has been made to trace all the copyright-holders, but if any have been inadvertently overlooked the publishers will be pleased to make the necessary arrangement at the first opportunity. 